\title{
$\frac{100}{\mathrm{WiT}}$ RPESS
}

\section{PODATEK DOCHODOWY OD OSÓB FIZYCZNYCH JAKO ŹRÓDŁO DOCHODÓW MIAST WOJEWÓDZKICH - KONTROWERSJE WOKÓŁ ZASAD PODZIAŁU}

\section{WPROWADZENIE}

Działalność jednostek samorząu terytorialnego (JST) wymaga wyposażenia ich w adekwatne do przypisanych zadań środki finansowe. Wśród tych środków szczególną pozycję zajmują dochody własne, do których w Polsce zalicza się między innymi wpływy z udziału w podatkach centralnych - podatku dochodowym od osób fizycznych (PIT) i od osób prawnych (CIT). O ile wyposażanie JST w tego rodzaju dochody jest rozwiązaniem powszechnie stosowanym w krajach europejskich, o tyle ich zaliczanie do dochodów własnych wydaje się kontrowersyjne ${ }^{1}$. Władza samorządowa nie dysponuje bowiem żadnymi instrumentami władztwa podatkowego wobec tego typu dochodu „własnego”. To władza ustawodawcza decyduje o wszystkich elementach prawnej konstrukcji tych podatków oraz sposobie podziału wpływów z ich tytułu pomiędzy szczeble samorządowe i państwo, co ma przełożenie na wielkość osiaganych dochodów przez JST. Zainteresowanie tym źródłem dochodów JST wynika z faktu, że stanowią one istotny udział w dochodach ogółem (i we własnych) samorządu terytorialnego.

Problemem, z którym muszą się zmagać JST (zwłaszcza duże miasta), jest sposób naliczania dochodów poszczególnym jednostkom z tego tytułu ${ }^{2}$. Aby dana jednostka mogła otrzymać dochody z udziału w PIT, podatnicy musza ja wskazać jako miejsce zamieszkania. JST nie otrzymują dochodów z podatków

* Dorota Wyszkowska, Uniwersytet w Białymstoku,

d.wyszkowska@uwb.edu.pl, https://orcid.org/0000-0003-1084-5341

** Adam Wyszkowski, Uniwersytet w Białymstoku, a.wyszkowski@uwb.edu.pl, https://orcid.org/0000-0001-7287-9534

1 Blöchliger, Petzold (2009); Blöchliger (2007); Wójtowicz (2013); Hanusz, Niezgoda, Czerski (2006); Poniatowicz, Dziemianowicz (2016).

2 Kotlińska (2015). 
dwóch grup osób. Pierwszą tworzą osoby, które mieszkają w danej jednostce, ale tego faktu nie zgłaszają; ; druga - osoby, które zamieszkuja poza granicami jednostki (najczęściej w gminach ościennych stanowiących tzw. sypialnie miast) i dojeżdżając codziennie do pracy, korzystają z wielu dóbr publicznych oferowanych przez tę jednostkę. Temu problemowi, tj. skutkom finansowym obecnego systemu przydziału środków z PIT dla miast wojewódzkich, poświęcony jest niniejszy artykuł. Postępujący proces suburbanizacji wokół dużych miast sprawia, że coraz większa liczba osób zamieszkuje gminy podmiejskie korzysta z usług i dóbr publicznych oferowanych przez miasta, nie partycypując jednak w kosztach ich dostawy ${ }^{4}$.

Władze samorządowe dużych miast prowadzą akcje promocyjne, zachęcające mieszkańców do dopełnienia obowiązku meldunkowego lub wskazania danego miasta jako miejsca zamieszkania, pozwalającego na osiaganie większych dochodów z tytułu wpływów z udziału w PIT. Często oferują zniżki w opłatach za usługi komunalne (np. komunikację miejska) osobom płacacym PIT w mieście.

Jednostki samorządowe nie mogą natomiast podejmować w zasadzie żadnych działań w celu zwiększenia wpływów budżetowych z tytułu udziału w PIT w przypadku osób dojeżdżających do pracy spoza terenu miasta, ponieważ sposób ich przypisania poszczególnym jednostkom jest ściśle określony w regulacjach prawnych. Przypisanie udziału w PIT danej jednostce jest jednoznacznie uzależnione od faktu zamieszkania podatnika na jej terenie.

Celem artykułu jest określenie wielkości środków, jakie traca miasta wojewódzkie z tytułu udziału w PIT w wyniku obowiązującego sposobu podziału tych dochodów pomiędzy jednostkami samorządu terytorialnego. Utracone potencjalne dochody zostały zaprezentowane w ujęciu bezwzględnym, jak również w porównaniu z wielkością dochodów z tytułu udziału w PIT oraz ogółu dochodów własnych. Analizę przeprowadzono za rok 2016 i dla porównania za rok 2011. Wybór lat do analizy podyktowany był dostępnością jedynego źródła danych dotyczących przemieszczania się ludności w związku z podejmowana praca poza miejscem zamieszkania ${ }^{5}$. Do analizy wykorzystano dane Ministerstwa Finansów oraz Głównego Urzędu Statystycznego. Oszacowania dokonano z uwzględnieniem zróżnicowania poziomu wynagrodzeń według województw oraz zmieniającej się efektywnej stopy opodatkowania dochodów podatkiem PIT. Analiza statystyczna została poprzedzona studiami literaturowymi w zakresie koncepcji, istoty oraz umiejscowienia udziałów w podatkach centralnych jako źródła dochodów JST (gmin).

\footnotetext{
${ }^{3}$ Furman (2017).

4 Bitner et al. (2015).

${ }^{5}$ Dane na temat dojazdów do pracy są opracowywane przez GUS na podstawie rozliczeń podatkowych udostępnianych przez Ministerstwo Finansów oraz na podstawie spisów powszechnych prowadzonych co 10 lat. Dane dotyczące roku 2021 będą dostępne po opracowaniu wyników spisu 2021. Nie ma innych źródeł danych umożliwiających dokonania szacunków w zakresie podjętym w niniejszym opracowaniu.
} 


\section{WPŁYWY Z UDZIAŁÓW W PODATKACH CENTRALNYCH JAKO ŹRÓDŁO DOCHODÓW GMIN - KONOTACJE TEORETYCZNE}

Od lat autorzy zajmujący się tematyką finansów samorządowych zastanawiaja się nad wypracowaniem optymalnych źródeł dochodów JST, z jednej strony zapewniających im stabilność dochodów, z drugiej zaś - określony poziom samodzielności finansowej. Władze lokalne zgodnie z regulacjami Europejskiej karty samorządu lokalnego (EKSL) powinny mieć prawo do wystarczających własnych zasobów, dzięki którym mogłyby, swobodnie nimi dysponując, wykonywać przypisane im zadania. Część środków musi pochodzić z opłat i podatków lokalnych, których poziom JST powinny ustalać samodzielnie, w granicach określonych prawem. W dokumencie tym nie znajdują się jednak zapisy wskazujące, jakie to mają być daniny, a także jaką część dochodów JST powinny stanowić. Wśród podatków lokalnych można wyróżnić6:

- podatki samoistne, czyli takie, które mogą być wprowadzane samodzielnie przez JST, w tym samoopodatkowanie się mieszkańców,

- podatki i opłaty ustalane odgórnie w trybie ustawowym, lecz w całości zasilające budżet JST,

- udziały w podatkach centralnych,

- dodatki do podatków centralnych bez ograniczeń bądź też z ustawowym ograniczeniem ich wysokości.

Szczególne miejsce wśród wymienionych źródeł dochodów podatkowych stanowią udziały w podatkach centralnych (tzw. podatki wspólne). Udział JST w podatkach oznacza ich uprawnienie do partycypowania w wykonanych dochodach budżetu państwa lub JST innego szczebla (tax sharing ${ }^{7}$ ). Partycypujacy $\mathrm{w}$ dochodach innego podmiotu, w tym przypadku JST, często nie ma wpływu ani na kształtowanie konstrukcji tego źródła dochodów, ani na jego wymiar i pobór ${ }^{8}$. Jego rola sprowadza się do przejmowania wpływów i ich rozdysponowywania ${ }^{9}$. Konstrukcja udziału w podatkach centralnych polega zwykle na zapewnieniu wszystkim JST danego szczebla z góry określonego udziału procentowego w dochodach podatkowych budżetu państwa lub innych podatkach, które stają się w ten sposób podatkami wspólnymi, dzielonymi według określonego algorytmu procentowego pomiędzy różne szczeble zarządzania państwem, od centralnego po lokalny. W praktyce funkcjonują kraje, w których tax sharing nie przejawia się wyłącznie w biernym partycypowaniu JST w dochodach z podatków centralnych, ale również w aktywnym kształtowaniu elementów prawnej konstrukcji podatków, w dopuszczalnym prawem zakresie. Dobrym przykładem sa tu zwłaszcza kraje skandynawskie, w których JST mają prawo kształtowania stawek lokalnych podatków dochodowych w pierwszym progu podatkowym, a dopiero po jego przekroczeniu uprawnienia przejmuje państwo.

\footnotetext{
${ }^{6}$ Kosek-Wojnar, Surówka (2007): 72-73.

${ }^{7}$ Roy (2006): 5; Blöchliger, Petzold (2009): 4-5; Blöchliger, King (2006): 12-13.

${ }^{8}$ Blöchliger, King (2006a): 15.

${ }^{9}$ Kańduła (2017): 220.
} 
Udziały JST w podatkach wspólnych można ujmować szeroko i wąsko. Sposoby definiowania udziałów JST w podatkach wspólnych zaprezentowano w tabeli 1.

\section{Tabela 1}

Udziały JST w podatkach wspólnych - ujęcie wąskie i szerokie

\begin{tabular}{|c|c|c|}
\hline Szeroka definicja & Cechy udziałów JST & Wąska definicja \\
\hline \multirow[b]{2}{*}{$\begin{array}{l}\text { Udziały w ścisłym znacze- } \\
\text { niu (stricte tax sharing) }\end{array}$} & $\begin{array}{l}\text { JST partycypują w ry- } \\
\text { zyku cyklicznych zmian } \\
\text { dochodów w podatku } \\
\text { wspólnym }\end{array}$ & Udziały „zwykłe” \\
\hline & $\begin{array}{l}\text { JST maja swobodę } \\
\text { wydatkowania docho- } \\
\text { dów z tytułu udziału } \\
\text { w podatku wspólnym }\end{array}$ & \multirow{2}{*}{$\begin{array}{l}\text { Kraje, w których występuja } \\
\text { udziały w waskim ujęciu: } \\
\text { Wielka Brytania (podatek } \\
\text { od nieruchomości), } \\
\text { Czechy (PIT), } \\
\text { Węgry (PIT), } \\
\text { Niemcy (VAT - w przypad- } \\
\text { ku landów) }\end{array}$} \\
\hline \multirow{2}{*}{$\begin{array}{l}\text { Kraje, w których występuja } \\
\text { udziały w szerokim ujęciu: } \\
\text { Polska (PIT, CIT) } \\
\text { Hiszpania (VAT i podatek } \\
\text { akcyzowy - w przypadku } \\
\text { regionów }\end{array}$} & $\begin{array}{l}\text { Konstrukcja prawna } \\
\text { dochodów z tytułu } \\
\text { udziału w podatku } \\
\text { wspólnym jest stabilna }\end{array}$ & \\
\hline & $\begin{array}{l}\text { Udziały dzielone sa } \\
\text { proporcjonalnie do } \\
\text { wysokości środków } \\
\text { wypracowanych na } \\
\text { terenie danej JST }\end{array}$ & \\
\hline
\end{tabular}

Źródło: opracowanie własne na podstawie: Kańduła (2017): 220.

Należy podkreślić, iż w przypadku, gdy choćby jedna z trzech pierwszych wymienionych $\mathrm{w}$ tabeli 1 cech nie została spełniona, oznacza to de facto, że udział w podatkach wspólnych będzie miał charakter subwencji lub dotacji, czyli dochodu transferowego. Tego typu udziały występuja w przypadku francuskich departamentów i regionów w odniesieniu do podatku od paliw i podatku od ubezpieczeń.

Udziały JST w podatkach wspólnych, często jako istotne źródło ich dochodów, mogą pełnić jedną lub więcej funkcji. Wśród nich należy wymienić funkcję fiskalna, wyrównawczą i stymulacyjną (aktywizująca) oraz stabilizacyjna ${ }^{10}$. Uwzględniając ich wielkość, w porównaniu z innymi źródłami dochodów oraz ich znaczenie $\mathrm{w}$ strukturze dochodów, można przyjąć, że w większości krajów, w których występuje to źródło dochodów, pełni ono funkcję finansowania zadań JST, czyli funkcję fiskalną. Udziały w podatkach wspólnych są instrumentem redystrybucji pionowej i poziomej, czyli pełnią funkcję głównie wyrównawczą ${ }^{11}$. Wynika to $\mathrm{z}$ faktu, że w przepisach określa się

${ }^{10}$ Kornberger-Sokołowska (2013): 117; Wójtowicz (2014): 138-139.

11 Kornberger-Sokołowska (2013): 118; Blöchliger, King (2006): 12. 
nie tylko zasady podziału podatków wspólnych między państwo i JST, ale także proporcje i kryteria przyznawania środków finansowych poszczególnym typom $\mathrm{JST}^{12}$.

Dyskusja na temat udziałów w podatkach wspólnych nie dotyczy zwykle funkcji, jakie one pełnia, ale gdzie są umiejscowione w strukturze dochodów JST, jak też w jaki sposób podlegają podziałowi. Odnosząc się do rozwiązań przyjętych w Polsce do końca lat dziewięćdziesiątych XX w., udziały w podatkach centralnych były, w myśl regulacji prawnych, odrębną kategorią dochodów. Takie ich ujęcie w katalogu dochodów odpowiadało poglądom wielu autorów zajmujących się tematyką finansów samorządowych ${ }^{13}$. Niektórzy autorzy akceptują także przypisanie tego źródła do dochodów własnych pod warunkiem, że sa to wpływy w rozumieniu szerokim (sensu largo $)^{14}$, w odróżnieniu od wpływów w ujęciu waskim, czyli sensu stricto ${ }^{15}$. W literaturze przedmiotu, zwłaszcza anglojęzycznej, prezentowany jest także pogląd, że udziały w podatkach centralnych (wspólnych) traktowane powinny być jako rodzaj transferów ${ }^{16}$. W klasyfikacjach międzynarodowych obok samego wyodrębnienia udziałów w podatkach centralnych (tax sharing) można spotkać także dodatkowy podział na: strict tax sharing oraz tax sharing ${ }^{17}$. Różnica między nimi ustalana jest z wykorzystaniem 4 kryteriów, a mianowicie:

- podział ryzyka - czy kwota dochodów przypisanych jednostkom jest ściśle związana z całkowitymi dochodami podatkowymi, tj. czy jednostki w pełni ponoszą ryzyko spadku dochodów podatkowych?

- bezwarunkowość - czy władze niższego szczebla mogą swobodnie wykorzystywać przydzielone dochody?

- stabilność formuły - czy podział dochodów między szczeblem centralnym a jednostkami samorządu jest z góry określony i nie zmienia się w trakcie roku podatkowego? - indywidualna proporcjonalność - czy udział w dochodach każdej jednostki samorządu jest ściśle powiązany z tym, co generuje ona na swoim terytorium?

Pierwsze trzy kryteria odnoszą się do relacji między władzami centralnymi i jednostkami samorządu terytorialnego, a czwarte dotyczy relacji pomiędzy JST. Przyjmuje się, że jeśli spełnione są wszystkie cztery kryteria, będzie to kategoria strict tax sharing. Jeżeli nie jest spełnione ostatnie kryterium (indywidualna proporcjonalność), będzie to tax sharing. W myśl tego podziału w Polsce w przypadku udziału w PIT występuje stricte tax sharing ${ }^{18}$.

W praktyce międzynarodowej przedmiotem podziału sa zwykle dochody z podatków dochodowych i konsumpcyjnych (stanowią podatki wspólne). Chociaż udział w podatkach różni się od transferów finansowanych z ogólnych dochodów rządu centralnego, oba systemy wykazują pewne podobień-

\footnotetext{
12 Por. Kańduła (2017): 223.

13 Kosek-Wojnar, Surówka (2007); Ruśkowski, Salachna (2007); Swianiewicz (2004).

14 Ofiarski (2008); Ruśkowski, Salachna (2007).

15 Sekuła (2007).

16 Boadway, Eyraud (2018): 26.

17 Blöchliger, Petzold (2009): 4-5; Petersen (2008): 23.

18 Por. Kańduła (2017): 220.
} 
stwa. Podobnie jak w przypadku transferów bezwarunkowych, JST moga wykorzystać fundusze z podziału dochodów na dowolny cel, jaki uznaja za stosowny. Ponadto fundusze te mogą być alokowane pomiędzy poszczególne JST według określonych zasad. Trzy powszechnie stosowane metody alokacji są następujące ${ }^{19}$ :

- przypisanie poszczególnym jednostkom dochodów w zależności od tego, gdzie pobierane są dzielone podatki (wspólne), co oznacza, że JST o wyższych zdolnościach do generowania dochodów osiagają wyższe dochody, co skutkuje poziomą dysproporcją w zwiększaniu dochodów ${ }^{20}$;

- przypisanie JST dochodów po wcześniejszej agregacji i rozdzielaniu między poszczególne jednostki w równych kwotach na mieszkańca, co skutkuje redystrybucją środków z JST o wyższych podstawach opodatkowania na mieszkańca do jednostek z niższą podstawą opodatkowania na mieszkańca;

- przypisanie JST dochodów po wcześniejszej agregacji i rozdzielaniu między poszczególne jednostki na podstawie sformułowanej celowo formuły, np. formuły wyrównania dochodów, albo zaspokojenia zwiększonych potrzeb w zakresie wydatków.

Podział podatków wspólnych może następować na podstawie ${ }^{21}$ :

- zawieranych porozumień o podziale podatków, w którym jednostki samorządu lokalnego określają podział dochodów;

- ustaleń strony rządowej, ale podział można zmienić tylko za zgodą władz lokalnych;

- przepisów prawa, może je zmieniać jednostronnie rząd centralny, ale rzadziej niż raz w roku;

- ustaleń corocznych przez rząd centralny.

Ujęcie analizowanego źródła dochodów JST jest zróżnicowane w poszczególnych systemach ewidencji, w tym statystycznej (w różnych bazach danych moga być prezentowane inaczej), co utrudnia prowadzenie analiz porównawczych pomiędzy krajami w tym zakresie, zwłaszcza określania stopnia samodzielności dochodowej JST. Rachunki narodowe (NA), europejski system rachunków narodowych i regionalnych (ESA), rządowe statystyki finansowe (GFS), statystyki dotyczące dochodów (RS) i Rada Europy (CE) wprowadzaja bowiem pewne kryteria podziału pomiędzy tym rodzajem dochodów a transferami do budżetów lokalnych. Kryteria te są różne (często niejasne) i wymagaja oceny zasad i przepisów kształtujących poszczególne systemy finansowania JST, co w niektórych krajach może być uciążliwe ${ }^{22}$.

W rzeczywistości umożliwienie JST korzystania z centralnych podstaw opodatkowania może zmniejszyć konkurencję pomiędzy JST, może odizolować je od odpowiedzialności za zmianę ich podstaw podatkowych ${ }^{23}$ i może generować iluzję podatkową do tego stopnia, że konsekwencje polityki podatkowej

\footnotetext{
19 Boadway, Eyraud (2018): 27-28.

20 Rozwiązanie obowiązujące w Polsce.

21 Blöchliger, Petzold (2009): 4-5.

22 Szerzej: Blöchliger, Petzold (2009).

${ }^{23}$ Zax (1988): 81-82.
} 
rządu centralnego dla dochodów lokalnych nie są dostrzegane przez mieszkańców. Według McKenzie i Staff może to prowadzić do istotnego wzrostu lokalnych wydatków ${ }^{24}$.

Biorąc pod uwagę różne ujęcia analizowanego źródła dochodów sektora samorządowego oraz jego specyfikę, wydaje się, że najwłaściwsze byłoby pozostawienie go jako odrębnej kategorii dochodów JST, bez przyporządkowania do dochodów własnych, czy też transferowych. Pozwoliłoby to na prowadzenie analiz porównawczych, jak też nie zakłócałoby oceny samodzielności dochodowej JST w różnych krajach i systemach, zwłaszcza gdy jednostki samorządu nie wykazują się władztwem podatkowym wobec tego źródła dochodów, jak ma to się dzieje w Polsce.

Jednak obecnie obowiąujące regulacje prawne w Polsce klasyfikują je do dochodów własnych. Ustawa zasadnicza wskazuje bowiem jedynie trzy źródła dochodów: własne, subwencję ogólną i dotacje celowe. W ustawie z 13 listopada 2003 r. o dochodach jednostek samorządu terytorialnego jednoznacznie przypisuje się udziały w podatkach centralnych do dochodów własnych. Rozwiązanie to jest, w zasadzie od momentu jego przyjęcia, krytykowane jako zabieg celowy prowadzący do pozornego zwiększania samodzielności dochodowej tych jednostek ${ }^{25}$.

Wydaje się, że przesłanką przyznania w pierwszej kolejności gminom, a następnie dwóm pozostałym poziomom JST w Polsce (powiatom i województwom), udziałów w PIT wygenerowanych na ich obszarze, miało być przede wszystkim uzupełnieniem ograniczonych dochodów z pozostałych źródeł ${ }^{26}$. Przyjęte rozwiązania miały także sprzyjać mobilizacji społeczności lokalnych do powiększania bazy podatkowej gmin. Jednak, jak zauważa Jarosław Olejniczak: „specyfika opodatkowania PIT-em w Polsce powoduje, iż takie założenie można uznać za wątpliwe. Podatek ten nie jest nadal podatkiem powszechnym, istnieje bowiem istotna grupa osób, które ustawowo podlegaja wyłączeniu spod jego regulacji, czyli osoby prowadzące działalność rolna" 27.

Udziały JST w podatkach centralnych sa jednak przez wielu autorów traktowane jako dochody transferowe (uzupełniajace). Argumentem przemawiającym za ich niezaliczaniem do kategorii dochodów własnych jest to, że w odniesieniu do nich trudno jest odnaleźć element władztwa podatkowego, które jest tożsame z wpływem władzy samorządowej na wydajność fiskalną tych dochodów. Jednocześnie trudno jest je umiejscowić w podziałach łącznie z transferami (zwłaszcza celowymi). Na tym tle pojawia się pytanie, jaki powinien zostać przyjęty klucz podziału dochodów z podatku dochodowego od osób fizycznych, skoro środki pozyskane z tego tytułu mają służyć finansowaniu zadań publicznych przypisanych poszczególnym jednostkom do realizacji. Czy fakt zamieszkania jest dobrym wyznacznikiem przypisania dochodów z tego tytułu konkretnym jednostkom, pomimo że jednostki te

\footnotetext{
24 Liberati, Sacchi (2013): 187.

25 Surówka (2004).

${ }^{26}$ Olejniczak (2016): 114.

27 Olejniczak (2016): 114.
} 
w różnym stopniu świadczą usługi czy też dostarczają lokalne dobra publiczne mieszkańcom płacącym PIT na ich terenie? Osoby te często korzystają za to z dóbr i usług świadczonych przez inne jednostki - często miasta mające szeroką ich ofertę - nie ponosząc żadnych ciężarów z tego tytułu (w zakresie dóbr i usług nieodpłatnych lub dofinansowywanych przez poszczególne JST). Jest to bardzo dotkliwe, zwłaszcza w przypadku dużych miast, w których dochody z PIT stanowią istotne źródło zasilania finansowego ich budżetów.

\section{ZNACZENIE DOCHODÓW Z UDZIALU W PIT W DOCHODACH GMIN W POLSCE - ANALIZA DANYCH EMPIRYCZNYCH}

Z regulacji Konstytucji RP wynika, że gminom i pozostałym JST powinien być zapewniony udział $\mathrm{w}$ dochodach publicznych odpowiednio do przekazanych im do realizacji zadań. Skoro więc ich dochody własne są niewystarczające, obowiązkiem państwa jest ich uzupełnienie. Dochodami uzupełniającymi gmin w Polsce są wpływy z tytułu udziałów w podatkach stanowiacych dochody budżetu państwa - podatku dochodowym od osób fizycznych (PIT) i podatku dochodowym od osób prawnych (CIT) ${ }^{28}$ oraz transfery w postaci subwencji ogólnej oraz dotacji celowych. Dochody te jednak nie mają obecnie w gminach charakteru uzupełniającego. W okresie 2010-2019 stanowiły znaczącą część ich dochodów własnych oraz dochodów ogółem (tab. 2).

Tabela 2

Udział dochodów z tytułu udziału w PIT w dochodach ogółem oraz własnych gmin w Polsce w latach 2010-2019 (w \%)

\begin{tabular}{|l|c|c|c|c|c|c|c|c|c|c|c|c|}
\hline & $\mathbf{2 0 1 0}$ & $\mathbf{2 0 1 1}$ & $\mathbf{2 0 1 2}$ & $\mathbf{2 0 1 3}$ & $\mathbf{2 0 1 4}$ & $\mathbf{2 0 1 5}$ & $\mathbf{2 0 1 6}$ & $\mathbf{2 0 1 7}$ & $\mathbf{2 0 1 8}$ & $\mathbf{2 0 1 9}$ \\
\cline { 2 - 11 } & \multicolumn{7}{|c|}{ Udział w dochodach ogółem } \\
\hline $\begin{array}{l}\text { gminy bez miast } \\
\text { na prawach } \\
\text { powiatu }\end{array}$ & 13,9 & 15,0 & 15,4 & 16,0 & 16,5 & 17,4 & 16,3 & 16,5 & 17,2 & 17,2 \\
\hline $\begin{array}{l}\text { miasta na pra- } \\
\text { wach powiatu } \\
\text { bez miast } \\
\text { wojewódzkich }\end{array}$ & 20,3 & 21,3 & 20,9 & 20,9 & 21,1 & 22,4 & 22,1 & 22,4 & 22,8 & 22,4 \\
\hline $\begin{array}{l}\text { miasta } \\
\text { wojewódzkie }\end{array}$ & 26,6 & 26,4 & 24,9 & 24,9 & 25,1 & 25,8 & 26,6 & 27,4 & 28,6 & 28,6 \\
\hline
\end{tabular}

${ }^{28}$ Mimo że klasyfikowane są one do dochodów własnych JST. 


\begin{tabular}{|l|c|c|c|c|c|c|c|c|c|c|}
\hline \multicolumn{2}{|c|}{ Udział w dochodach własnych } \\
\hline $\begin{array}{l}\text { gminy bez miast } \\
\text { na prawach } \\
\text { powiatu }\end{array}$ & 31,2 & 32,9 & 33,1 & 33,3 & 33,5 & 35,1 & 36,8 & 38,1 & 39,7 & 39,7 \\
\hline $\begin{array}{l}\text { miasta na pra- } \\
\text { wach powiatu bez } \\
\text { miast wojewódz- } \\
\text { kich }\end{array}$ & 37,1 & 39,8 & 39,2 & 38,7 & 38,8 & 40,2 & 41,6 & 42,3 & 43,4 & 44,5 \\
\hline $\begin{array}{l}\text { miasta } \\
\text { wojewódzkie }\end{array}$ & 38,8 & 38,6 & 38,2 & 37,1 & 37,2 & 38,3 & 40,3 & 41,6 & 43,4 & 45,4 \\
\hline
\end{tabular}

Źródło: opracowanie własne na podstawie danych zawartych w Banku Danych Lokalnych, <https://bdl. stat.gov.pl/BDL/dane/podgrup/temat> [dostęp: 19.11.2020].

Jak można zauważyć, znaczenie fiskalne dochodów z analizowanego źródła jest zdecydowanie większe w przypadku miast na prawach powiatu, a w szczególności analizowanych miast wojewódzkich ${ }^{29}$, niż pozostałych gmin. Zróżnicowanie udziału dochodów w PIT w polskich gminach jest dość duże. Wartość współczynnika zmienności dla gmin (bez miast na prawach powiatu) w analizowanym okresie wahała się w granicach $25-41 \%$, podczas gdy w miastach na prawach powiatu kształtowała się na poziomie 12-15\%, podobnie jak w przypadku samych miast wojewódzkich (współczynnik zmienności 13-16\%). Niższy poziom zróżnicowania w miastach wynikać może $\mathrm{z}$ bardziej zbliżonego niż $\mathrm{w}$ pozostałych gminach poziomu potencjału dochodowego tych jednostek. Część mieszkańców gmin wiejskich, również tych położonych w bezpośrednim sąsiedztwie miast, zajmuje się nieopodatkowana podatkiem dochodowym działalnościa rolnicza, część natomiast działalnością opodatkowaną. Proporcje pomiędzy tymi grupami ludności moga być silnie zróżnicowane.

Zarówno w przypadku gmin, miast na prawach powiatu, jak i miast wojewódzkich znaczenie dochodów z udziału w PIT w analizowanym okresie wzrastało. W ostatnich 5 latach udział tego typu dochodów wzrósł w dochodach własnych miast na prawach powiatu o blisko 6 punktów procentowych, a w pozostałych gminach o blisko 5 punktów procentowych, natomiast w przypadku miast wojewódzkich o nieco ponad 7 punktów procentowych. Wzrost tych udziałów w dochodach ogółem był mniejszy.

Wśród miast na prawach powiatu większym udziałem dochodów z PIT charakteryzuja się budżety części miast wojewódzkich. Wartości minimalne, maksymalne i średnie dochodów z udziału w PIT w dochodach ogółem oraz dochodach własnych miast wojewódzkich przedstawiono w tabeli 3.

${ }^{29}$ Miasta te to: Wrocław, Bydgoszcz, Toruń, Lublin, Gorzów Wielkopolski, Zielona Góra, Łódź, Kraków, Warszawa, Opole, Rzeszów, Białystok, Gdańsk, Katowice, Kielce, Olsztyn, Poznań oraz Szczecin. 
Tabela 3

Udział dochodów z tytułu udziału w PIT w dochodach ogółem oraz własnych miast wojewódzkich w Polsce w latach 2010-2019 (w \%)

\begin{tabular}{|l|c|c|c|c|c|c|c|c|c|c|c|}
\hline & $\mathbf{2 0 1 0}$ & $\mathbf{2 0 1 1}$ & $\mathbf{2 0 1 2}$ & $\mathbf{2 0 1 3}$ & $\mathbf{2 0 1 4}$ & $\mathbf{2 0 1 5}$ & $\mathbf{2 0 1 6}$ & $\mathbf{2 0 1 7}$ & $\mathbf{2 0 1 8}$ & $\mathbf{2 0 1 9}$ \\
\cline { 2 - 11 } & \multicolumn{10}{|c|}{ Udział w dochodach ogółem } \\
\hline min & 17,78 & 18,54 & 17,92 & 19,09 & 16,73 & 17,47 & 19,74 & 20,13 & 19,78 & 20,33 \\
\hline średnia & 24,06 & 24,33 & 23,11 & 22,73 & 23,05 & 23,83 & 24,27 & 24,58 & 25,36 & 25,03 \\
\hline max & 32,22 & 30,47 & 29,47 & 30,09 & 28,80 & 29,88 & 31,51 & 32,57 & 33,83 & 34,87 \\
\hline \multicolumn{10}{|c|}{ Udział w dochodach własnych } \\
\hline min & 30,77 & 29,09 & 30,52 & 30,89 & 26,52 & 33,95 & 35,44 & 38,07 & 38,71 & 40,02 \\
\hline średnia & 39,53 & 39,91 & 39,30 & 38,06 & 37,50 & 39,02 & 40,31 & 41,34 & 42,87 & 44,25 \\
\hline max & 45,22 & 45,65 & 46,88 & 45,10 & 45,37 & 49,46 & 50,37 & 46,57 & 49,24 & 51,45 \\
\hline
\end{tabular}

Źródło: opracowanie własne na podstawie danych zawartych w Banku Danych Lokalnych, <https://bdl. stat.gov.pl/BDL/dane/podgrup/temat> [dostęp: 19.11.2020].

W całym analizowanym okresie maksymalnymi wartościami udziałów w odniesieniu do dochodów ogółem charakteryzowało się miasto stołeczne Warszawa, natomiast w relacji do dochodów własnych - Zielona Góra (wyjątek lata 2010-2011). Wartości minimalne odnosiły się do różnych miast w poszczególnych latach.

Zaprezentowane dane potwierdzaja znaczenie fiskalne analizowanego źródła dochodów budżetów gmin w Polsce, zwłaszcza miast wojewódzkich. Nierozpoznane dotychczas pozostaje, o ile dochody tych jednostek wzrosłyby, gdyby przejęto inny sposób ich naliczania niż obowiązujący. Chodzi zarówno o zasygnalizowany we wstępie problem zamieszkiwania osób na terenie danej gminy i niezgłaszanie tego faktu oraz postępująca suburbanizację wokół dużych miast, osiedlanie się mieszkańców poza ich granicami administracyjnymi i korzystanie z dóbr i usług przez nie oferowanych.

W dalszej części artykułu podjęto próbę oszacowania wielkości utraconych potencjalnych dochodów miast wojewódzkich, wynikajacych z zamieszkiwania ludności na obrzeżach tych miast i przemieszczania się - w związku z dojazdami do pracy lub też faktu zamieszkiwania i pracy na obszarze danej jednostki bez zgłoszenia zmiany miejsca zamieszkania.

\section{METODA BADAWCZA}

Dane dotyczące wielkości osiaganych dochodów z tytułu udziału w PIT w dochodach ogółem i dochodach własnych zaprezentowano na podstawie sprawozdań budżetowych miast wojewódzkich dostępnych na stronie internetowej Ministerstwa Finansów. Wielkości utraconych potencjalnych dochodów z udziału w PIT, wynikające ze sposobu ich naliczania zostały obliczone 
z wykorzystaniem danych statystyki publicznej oraz Ministerstwa Finansów, a mianowicie:

- danych dotyczaccych przemieszczania się ludności w związku z podejmowana praca poza miejscem zamieszkania ${ }^{30}$ - dane te pochodzą z badania dojazdów do pracy opracowanych na podstawie administracyjnych źródeł danych: Ministerstwa Finansów i Zakładu Ubezpieczeń Społecznych. Zgodnie z przyjęta metodyką badania w liczbie dojeżdżających do pracy uwzględnione zostały przepływy między gminami danego województwa i innych województw ${ }^{31}$, w badaniu została dokonana identyfikacja terytorialna miejsc zatrudnienia osób pracujących (pracowników najemnych) poza jednostką administracyjną zamieszkania. Informacja ta w połączeniu z danymi o miejscu zamieszkania tych osób pozwoliła wyznaczyć natężenie i kierunki przepływów ludności związanych z pracą. W celu dokonania szacunków utraty potencjalnych dochodów z tytułu analizowanego źródła dochodów gmin skompensowano liczbę osób, które zamieszkuja daną gminę, ale pracują w innej gminie (wyjeżdzających), i osób, które mieszkają w innej gminie, ale pracują w danej gminie (przyjeżdżających);

- przeciętnego miesięcznego wynagrodzenia w miastach wojewódzkich dane te pochodzą z zasobów statystyki publicznej, są to informacje na temat przeciętnego miesięcznego wynagrodzenia brutto w gospodarce narodowej według województw, dane dla miast wojewódzkich nie są bowiem dostępne w statystyce publicznej, dane te podawane są w ujęciu brutto, tj. łącznie z zaliczkami na poczet podatku dochodowego od osób fizycznych oraz ze składkami na obowiązkowe ubezpieczenia społeczne (emerytalne, rentowe i chorobowe) płaconymi przez ubezpieczonego pracownika;

- efektywnej stawki opodatkowania podatkiem dochodowym od osób fizycznych na zasadach ogólnych prezentowanej przez Ministerstwo Finansów ${ }^{32}$. Efektywna stawka opodatkowania jest to stosunek kwoty ostatecznie należnego podatku do wartości podstawy opodatkowania (po uwzględnieniu kosztów uzyskania przychodów oraz składek na ubezpieczenia społeczne). Efektywna stopa opodatkowania jest wyliczana z uwzględnieniem wykorzystania ulg podatkowych przez podatników, i w 2016 r stawka ta wyniosła 7,40\%, natomiast w $2011-6,82 \%{ }^{33}$.

W szacunkach nie uwzględniono osób fizycznych prowadzących działalność gospodarczą i rozliczających się z PIT na zasadach podatku liniowego (dotyczy to wyłącznie przedsiębiorców). W obliczeniach nie uwzględniono także emerytów i rencistów pobierających świadczenia społeczne ${ }^{34}$. W obu przypadkach nie

${ }^{30}$ GUS (2011). Dane te zostały opracowane na podstawie rozliczenia PIT z uwzględnieniem podwyższonych kosztów uzyskania przychodów z tytułu innego miejsca zamieszkania w stosunku do miejsca położenia zakładu pracy.

${ }^{31}$ Co oznacza, że w prezentowanych wielkościach zostały ujęte także osoby zameldowane i rozliczające się z PIT w jednej gminie, a zamieszkujące w innej gminie, bez zgłoszenia tego faktu.

32 MF (2017), MF (2012).

${ }^{33}$ Ze względu na strukturę podatników według przynależności do progów podatkowych do wyliczeń przyjęto efektywną stopę podatkową właściwą dla pierwszego progu podatkowego.

34 Wydaje się jednak, że fakt płacenia PIT na terenie jednej gminy, a zamieszkiwania na obszarze innej, nie jest zjawiskiem powszechnym w grupie emerytów i rencistów, co nie powinno istotnie zniekształcać oszacowanych wielkości. 
było możliwe określenie natężenia analizowanego zjawiska (różnych miejsc zamieszkania i korzystania z dóbr oraz usług publicznych). Analizując wielkość utraconych potencjalnych dochodów z PIT w poszczególnych jednostkach samorządu, należy mieć na uwadze, że są one jednak niedoszacowane w wyżej wymienionym zakresie.

Oszacowanie wielkości utraconych potencjalnych dochodów z tytułu udziału w PIT miast wojewódzkich rozpoczęto od ustalenia liczby osób przyjeżdzających i wyjeżdżających, a następnie skorygowano wielkość przeciętnego miesięcznego wynagrodzenia brutto w gospodarce narodowej w każdym województwie o koszty uzyskania przychodów oraz obowiązkowe składki na ubezpieczenia społeczne płacone przez pracownika.

W dalszej kolejności została obliczona wysokość podatku dochodowego od osób fizycznych z uwzględnieniem efektywnej stopy opodatkowania za dany rok, publikowanej przez Ministerstwo Finansów. Następnie oszacowano wielkość rocznych potencjalnych dochodów z udziału w PIT w poszczególnych miastach wojewódzkich. Wielkości te zaprezentowano w wartościach bezwzględnych, jak również $\mathrm{w}$ odniesieniu do osiaganych dochodów $\mathrm{z}$ analizowanego źródła dochodów oraz dochodów własnych.

Obliczenia wykonano dla dwóch lat 2016 i 2011. Ograniczenie czasowe prowadzonej analizy wynika z dostępności danych dotyczacych natężenia przemieszczania się ludności w związku z podejmowaną pracą poza miejscem zamieszkania. Poza wykorzystanym źródłem danych nie są dostępne żadne nowsze wiarygodne informacje na ten temat. Dane dotyczące roku 2021 będą możliwe do wykorzystania w badaniach po opracowaniu wyników Narodowego Spisu Powszechnego Ludności i Mieszkań 2021 (w roku 2022 lub 2023).

\section{WYNIKI BADANIA}

Jak już zauważono, dochody z udziału w PIT stanowią istotna część dochodów budżetowych miast wojewódzkich w Polsce. Opisany sposób naliczania dochodów z tego tytułu poszczególnym jednostkom powoduje ubytek ich potencjalnych dochodów z analizowanego źródła. W roku 2016 oszacowana wielkość utraty potencjalnych dochodów miast wojewódzkich w Polsce wyniosła nieco ponad $1 \mathrm{mld}$ zł. Największy ubytek potencjalnych dochodów oszacowano dla miasta stołecznego Warszawy (blisko $367 \mathrm{mln}$ zł), Katowic (prawie $145 \mathrm{mln}$ zł) oraz Krakowa (nieco ponad $86 \mathrm{mln}$ zł), natomiast najmniejszy przypadł na Gorzów Wielkopolski (niespełna $4 \mathrm{mln}$ zł) oraz Białystok (blisko 7,3 mln zł). Wielkość oszacowanych utraconych potencjalnie dochodów w 2016 r. była wyższa o blisko 190 mln zł względem 2011 r., tj. o nieco $22 \%$ więcej. W roku 2011 największy ubytek, według przeprowadzonego szacunku, przypadł na miasto stołeczne Warszawę (blisko $313 \mathrm{mln}$ zł), Katowice (niespełna $133 \mathrm{mln}$ zł) oraz Poznań (nieco ponad $65 \mathrm{mln}$ zł). Minimalne wartości oszacowano ponownie w przypadku Gorzowa Wielkopolskie- 
go (nieco ponad $3 \mathrm{mln}$ zł) oraz Białegostoku (nieco ponad $7 \mathrm{mln}$ zł). Analizując te wartości w ujęciu bezwzględnym, należy jednak pamiętać o wielkości poszczególnych jednostek, mierzonej liczbą mieszkańców, a także o różnicach w poziomie wynagrodzeń, które w szacunkach odgrywają dość istotna rolę. Współczynnik zmienności poziomu wynagrodzeń w 2016 r. wynosił blisko $12 \%$, przy wartości max 5,73 tys. zł i min 3,67 tys. zł, natomiast w 2011 r. współczynnik zmienności osiagnął poziom 14\%, przy wartości max 5,01 tys. zł i min 3,25 tys. zł. Wartość utraconych potencjalnych dochodów z tytułu udziału w PIT w dochodach $\mathrm{z}$ tego tytułu oraz $\mathrm{w}$ dochodach własnych miast wojewódzkich została zaprezentowana w tabeli 4 .

Tabela 4

Ubytek potencjalnych dochodów z tytułu udziału w PIT w dochodach z tego źródła oraz w dochodach własnych miast wojewódzkich w Polsce w roku 2016 i 2011 (w \%)

\begin{tabular}{|c|c|c|c|c|}
\hline \multirow{3}{*}{$\begin{array}{c}\text { Miasto } \\
\text { wojewódzkie }\end{array}$} & \multicolumn{4}{|c|}{$\begin{array}{l}\text { Udział ubytku potencjalnych dochodów z tytułu udziału } \\
\text { w PIT }\end{array}$} \\
\hline & \multicolumn{2}{|c|}{2016} & \multicolumn{2}{|c|}{2011} \\
\hline & $\begin{array}{l}\text { w dochodach } \\
\text { własnych }\end{array}$ & $\begin{array}{c}\text { w dochodach } \\
\text { z udziału } \\
\text { w PIT }\end{array}$ & $\begin{array}{l}\text { w dochodach } \\
\text { własnych }\end{array}$ & $\begin{array}{c}\text { w dochodach } \\
\text { z udziału } \\
\text { w PIT }\end{array}$ \\
\hline Wrocław & 2,5 & 7,0 & 1,9 & 6,5 \\
\hline Bydgoszcz & 2,0 & 5,0 & 1,9 & 5,2 \\
\hline Toruń & 1,8 & 4,3 & 1,7 & 4,2 \\
\hline Lublin & 3,5 & 8,2 & 3,6 & 8,4 \\
\hline Gorzów Wielkopolski & 1,2 & 3,2 & 1,5 & 3,5 \\
\hline Zielona Góra & 3,0 & 6,0 & 3,8 & 8,5 \\
\hline Łódź & 1,6 & 4,4 & 1,4 & 3,6 \\
\hline Kraków & 2,8 & 7,0 & 2,7 & 6,7 \\
\hline Warszawa & 3,3 & 7,9 & 3,6 & 9,1 \\
\hline Opole & 6,0 & 15,0 & 5,4 & 13,3 \\
\hline Rzeszów & 9,0 & 21,1 & 9,1 & 21,1 \\
\hline Białystok & 0,9 & 2,2 & 1,1 & 2,9 \\
\hline Gdańsk & 1,9 & 4,8 & 2,1 & 5,6 \\
\hline Katowice & 11,9 & 30,5 & 13,5 & 35,4 \\
\hline Kielce & 3,5 & 8,8 & 3,3 & 8,8 \\
\hline Olsztyn & 2,1 & 5,4 & 3,1 & 6,9 \\
\hline Poznań & 3,8 & 8,8 & 3,8 & 9,1 \\
\hline Szczecin & 0,9 & 2,6 & 1,9 & 4,2 \\
\hline Razem & 3,21 & 7,95 & 3,3 & 8,7 \\
\hline
\end{tabular}

Źródło: opracowanie własne na podstawie danych GUS, <https://stat.gov.pl/publikacje/publikacje-a-z> oraz <https://bdl.stat.gov.pl/BDL/dane/podgrup/temat> [dostęp: 19.11.2020]. 
Oszacowane wielkości utraconych potencjalnych dochodów miast wojewódzkich wydają się istotne z punktu widzenia osiaganych przez nie dochodów budżetowych. Należy zauważyć, że znaczenie to jest zróżnicowane. Mimo że kwotowo największą potencjalną stratę odnotowuje Warszawa, to procentowo: Katowice, Rzeszów oraz Opole. W przypadku pierwszego z trzech wymienionych miast od kilku lat obserwuje się spadek liczby ludności, co spowodowało, że Katowice nie sa już w dziesiątce miast o największej liczbie ludności w Polsce. Jednocześnie rośnie liczba mieszkańców miast sąsiadujących. Ubytek liczby ludności w tym mieście na przestrzeni 10 lat wyniósł ok. $6 \%{ }^{35}$. Analizując przypadek Katowic, należy mieć na uwadze, że jest ono położone na obszarze konurbacji ślasskiej.

Ciekawym przypadkiem jest natomiast miasto Rzeszów, w którym liczba ludności w tym samym czasie istotnie wzrosła (blisko o 10\%), a mimo wszystko oszacowany ubytek jest także znaczący w porównaniu z dochodami z analizowanego źródła oraz z dochodami własnymi. Miasto to dość szybko się rozwija, co skutkuje także rozwojem gmin sąsiadujących, stanowiących, podobnie jak w przypadku pozostałych miast wojewódzkim, tzw. sypialnie miast.

Lokaty poszczególnych miast według wielkości utraconych potencjalnych dochodów nie zmieniły się zasadniczo w 2016 r. w stosunku do 2011 r. Zestawienie wielkości utraconych potencjalnych dochodów w obu analizowanych latach wraz z lokatami zaprezentowano w tabeli 5.

\section{Tabela 5}

Ubytek potencjalnych dochodów z tytułu udziału w PIT miast wojewódzkich w Polsce w roku 2016 i 2011 (w zł)

\begin{tabular}{|l|c|c|c|c|}
\hline \multirow{2}{*}{$\begin{array}{c}\text { Miasto } \\
\text { wojewódzkie }\end{array}$} & \multicolumn{2}{c|}{ Wartość } & \multicolumn{2}{c|}{ Lokata } \\
\cline { 2 - 5 } & $\mathbf{2 0 1 6}$ & $\mathbf{2 0 1 1}$ & $\mathbf{2 0 1 6}$ & $\mathbf{2 0 1 1}$ \\
\hline Warszawa & 366349438 & 312915026 & 1 & 1 \\
\hline Katowice & 144389468 & 132882265 & 2 & 2 \\
\hline Kraków & 86065974 & 61328965 & 3 & 4 \\
\hline Poznań & 80857064 & 65281973 & 4 & 3 \\
\hline Wrocław & 72350988 & 48943904 & 5 & 5 \\
\hline Rzeszów & 48659191 & 33883459 & 6 & 6 \\
\hline Łódź & 40315355 & 25502393 & 7 & 9 \\
\hline Lublin & 34864401 & 27141142 & 8 & 8 \\
\hline Gdańsk & 33944865 & 29136199 & 9 & 10 \\
\hline Opole & 26067958 & 18085609 & 10 & 11 \\
\hline Kielce & 21113128 & 16830626 & 11 & 12 \\
\hline Bydgoszcz & 20807166 & 16562550 & 12 & \\
\hline
\end{tabular}

${ }^{35}$ GUS. BDL, <https://bdl.stat.gov.pl/BDL/dane/podgrup/temat>. 


\begin{tabular}{|l|r|r|r|l|}
\hline Szczecin & 12862639 & 16191415 & 13 & 13 \\
\hline Olsztyn & 12273484 & 12110557 & 14 & 14 \\
\hline Zielona Góra & 11996812 & 10104803 & 15 & 15 \\
\hline Toruń & 10397418 & 7729298 & 16 & 16 \\
\hline Białystok & 7243948 & 7164411 & 17 & 17 \\
\hline Gorzów Wielkopolski & 3971676 & 3160952 & 18 & 18 \\
\hline
\end{tabular}

Źródło: opracowanie własne na podstawie danych GUS, $<$ https://stat.gov.pl/publikacje/publikacje-a-z> oraz $<$ https://bdl.stat.gov.pl/BDL/dane/podgrup/temat> [dostęp: 19.11.2020].

Oszacowane wielkości potwierdzaja, że miasta największe, które stanowią najbardziej atrakcyjne miejsce pracy, traca najwięcej na przyjętym sposobie naliczania dochodów z PIT. Udział z PIT osób mieszkających w tych miastach, ale niezgłaszających zmiany miejsca zamieszkania oraz mieszkańców gmin ościennych codziennie dojeżdżających do miasta zasila budżety innych jednostek. Miasta wojewódzkie, nie osiagając dochodów z tego tytułu, muszą świadczyć usługi i dostarczać dobra publiczne zdecydowanie większej liczbie osób niż ta, od której otrzymują udziały z PIT.

Otwarte i zasadne pozostaje więc pytanie, czy nie należałoby dokonać zmian w sposobie podziału środków pochodzących z podatku dochodowego od osób fizycznych pomiędzy JST. Czy jednostki, na terenie których pracuja, a często i mieszkają osoby (niezgłaszające tego faktu), nie powinny partycypować w określonej części w dochodach z analizowanego źródła? Zapewne skomplikowałoby to obecnie funkcjonujaccy system podziału, ale zasadne wydaje się podjęcie tego zagadnienia, choćby w przypadku największych miast w Polsce miast wojewódzkich.

\section{PODSUMOWANIE I WNIOSKI}

Sama idea wykorzystania udziałów w podatkach centralnych, w tym PIT, jako dochodu budżetów JST (w tym gmin), oceniana jest pozytywnie ${ }^{36}$. Nie ulega wątpliwości, że obecnie w Polsce udziały w podatku PIT stanowią znaczące, pod względem fiskalnym, źródło dochodów gmin. Żaden samorząd lokalny nie wyobraża sobie budżetu bez tego typu dochodów. Największymi odbiorcami dochodów z tytułu podatków wspólnych, w tym PIT, są miasta wojewódzkie. Jednocześnie władze tych jednostek prezentują pogląd, że przyjęty ustawowo algorytm podziału udziału w PIT pomiędzy jednostkami jest krzywdzacy dla dużych miast. Muszą one dostarczać dobra i usługi publiczne nie tylko osobom, których część dochodów z udziału w PIT zasila ich budżety. Obsługuja także osoby zamieszkujace i niezgłaszające tego faktu oraz mieszkańców gmin ościennych dojeżdżających do miasta do pracy. Osoby te, zarówno w pierw-

\footnotetext{
36 Surówka (2008): 97; Sochacka-Krysiak (2008): 18.
} 
szym, jak i w drugim przypadku, korzystają z infrastruktury oraz innych dóbr i usług publicznych oferowanych w szerokim zakresie właśnie przez te miasta, nie partycypujac w kosztach ich udostępnienia (mowa tu o dobrach i usługach nieodpłatnych lub dotowanych przez jednostki). Stanowisko takie potwierdzane jest $\mathrm{w}$ wielu badaniach dotyczących zasilania finansowego JST. Według Janiny Kotlińskiej: „efektem istniejącej konstrukcji podziału dochodów gmin z tytułu udziału w podatku PIT jest »bogacenie się" gmin obwarzankowych (częstokroć wiejskich) kosztem ubożenia dużych miast, w promieniu oddziaływania których się one znajdują" ${ }^{37}$.

Należy uznać, że przyjęte ustawowo rozwiązanie w zakresie przypisywania jednostkom dochodów z tytułu PIT nie jest doskonałe. Nawiazuje ono do miejsca zamieszkania podatnika (osoby często nie zgłaszają zmiany miejsca zamieszkania), nie uwzględnia zaś miejsca (gminy), w którym pozyskuje on dochody z pracy. Efektem tego rozwiązania jest korzystanie przez jedne gminy z wpływów z tytułu udziału w zapłaconym przez podatników podatku dochodowym, podczas gdy inne gminy zaspokajają i finansują przynajmniej częściowo ich potrzeby w zakresie korzystania z dóbr i usług publicznych.

Konieczna wydaje się zatem zmiana sposobu podziału dochodów z podatku PIT między JST. Istniejąca sytuacja budzi dziś wiele kontrowersji, zwłaszcza wśród włodarzy dużych miast. Zmiana ta mogłaby polegać na zasygnalizowanym już podziale środków pochodzących z podatku dochodowego od osób fizycznych pomiędzy JST (uwzględnienie miejsca zamieszkania, jak i miejsca otrzymywania dochodów - pracy) lub też zbudowaniu algorytmu podziału środków z udziału w PIT, pozwalającego na traktowanie dużego miasta i gmin go otaczających (aglomeracji, miejskich obszarów funkcjonalnych, lokalnych rynków pracy) jako całości. Rozwój terenów podmiejskich (gmin okalających miasta) jest bowiem możliwy dzięki rozwojowi miast oraz oferowanych w nich miejsc pracy i szerokiego zestawu dóbr i usług publicznych. Powinny one zatem partycypować $\mathrm{w}$ dochodach z udziału w PIT nie tylko swoich mieszkańców, lecz także tych osób, które niedopełniają obowiązku zgłoszenia faktu zamieszkania w mieście, oraz tych, które codziennie przemieszczają się do pracy, korzystając z dóbr i usług oferowanych przez miasto.

Bitner, M., Gałąka, A., Sierak, J., Swianiewicz, P. (2015). Analiza funkcjonującego systemu wyrównywania dochodów JST wraz z propozycją jego modyfikacji. Ministerstwo Infrastruktury i Rozwoju. Warszawa.

Blöchliger, H., King, D. (2006). Fiscal autonomy sub-central governments. OECD Network on Fiscal Relations Across Levels of Government. Working Paper 2.

Blöchliger, H., King, D. (2006a). Less than you thought: the fiscal autonomy of sub-central governments. OECD Economic Studies 43. Paris.

Blöchliger, H. (2007). The fiscal autonomy of sub-central governments. <https://www.oecd.org/tax/ federalism/42982242.pdf>.

Blöchliger, H., Petzold, O. (2009). Finding the dividing line between tax sharing and grants: a statistical investigation. OECD Network on Fiscal Relations Across Levels of Government 10. $<$ https://www.oecd.org/tax/federalism/43072896.pdf>.

${ }^{37}$ Kotlińska (2015): 50. 
Boadway, R., Eyraud, L. (2018). Designing sound fiscal relations across government levels in decentralized countries. IMF Working Paper WP/18/271.

Furman, Ł. (2017). Znaczenie udziałów we wpływach w podatkach dochodowych stanowiących dochód budżetu państwa dla jednostek samorządu terytorialnego w Polsce w latach 2010-2015. Prace Naukowe Uniwersytetu Ekonomicznego we Wrocławiu 485: 134-152.

GUS (2011). Dojazdy do pracy. Narodowy Spis Powszechny Ludności i Mieszkań 2011. <http:// stat.gov.pl/spisypowszechne/nsp-2011/nsp-2011-wyniki/dojazdy-do-pracy-nsp-2011,7,1. html>.

GUS (2019). Dojazdy do pracy. [Dokument niepublikowany].

Hanusz, A., Niezgoda, A., Czerski, P. (2006). Dochody budżetu gmin. Warszawa: Wolters Kluwer.

Kańduła, S. (2017). W sprawie funkcji wyrównawczej udziałów jednostek samorządu terytorialnego w podatkach wspólnych. Prace Naukowe Uniwersytetu Ekonomicznego we Wrocławiu 485: 218-229.

Kornberger-Sokołowska, E. (2013). Zasada adekwatności w systemie finansów samorządu terytorialnego w Polsce. Warszawa: LexisNexis.

Kosek-Wojnar, M., Surówka, K. (2007). Podstawy finansów samorządu terytorialnego. Warszawa: Wydawnictwo Naukowe PWN.

Kotlińska, J. (2015). Podział dochodów publicznych między państwo a samorząd terytorialny. Roczniki Ekonomiczne Kujawsko-Pomorskiej Szkoły Wyższej w Bydgoszczy 8: 34-52.

Liberati, P., Sacchi, A. (2013). Tax decentralisation and local government size. Public Choice 157(1): 183-205.

Ministerstwo Finansów (2012). Informacja dotycząca rozliczenia podatku dochodowego od osób fizycznych za $2011 \mathrm{r}$. Warszawa.

Ministerstwo Finansów (2017). Informacja dotycząca rozliczenia podatku dochodowego od osób fizycznych za 2016 r. Warszawa.

Olejniczak, J. (2016). Znaczenie udziałów w podatkach stanowiących dochody budżetu państwa dla budżetów gmin miejskich województwa dolnośląskiego w latach 1996-2014. Prace Naukowe Uniwersytetu Ekonomicznego we Wrocławiu 425: 111-124.

Olejniczak, J. (2015). Fiscal efficiency and stability of own revenues in urban local self-governments' budgets before, during and after crisis - example from Lower Silesian voivodeship. 18th International Colloquium on Regional Sciences, Conference Proceedings, Masarykova Univerzita Ekonomicko-Spravni Fakulta, Katedra Regionalni Ekonomie a Spravy. <https:// www.researchgate.net/publication/278673586_Fiscal_efficiency_and_stability_of_own_revenues_in_urban_local_self-governments'_budgets_before_during_and_after_crisis_-_example_from_Lower_Silesian_voivodeship>.

Ofiarski, Z. (2008). Ocena zmian w konstrukcji podatków i opłat stanowiących źródła dochodów własnych gmin, [w:] L. Patrzałek (red.), Wybrane problemy finansów samorządu terytorialnego. Poznań: Wydawnictwo Szkoły Bankowej w Poznaniu: 153-168.

Petersen, H.G. (2008). Integration, decentralization, taxation, and revenue sharing: Good governance, sustainable fiscal policy and poverty reduction as peace-keeping strategies. Paper prepared for the GTZ-Director's Seminar for the General Secretariat of the EAC on Tax Harmonization and Regional Integration. Arusha/Tanzania. April 23/24. <https://www.econstor. eu/bitstream/10419/39666/1/589064215.pdf>.

Poniatowicz, M., Dziemianowicz, R. (2016). Udziały samorządu terytorialnego w państwowych podatkach dochodowych $\mathrm{w}$ aspekcie postulatów teoretycznych federalizmu fiskalnego. Annales Universitatis Mariae Curie-Skłodowska Lublin - Polonia Sectio H, Vol. L 1: 295-303.

Roy, G. (2006). Grants versus tax sharing: the extent of central government control, 46th Congress of the European Regional Science Association: "Enlargement, Southern Europe and the Mediterranean", August 30th - September 3rd, 2006, Volos, Greece, European Regional Science Association (ERSA), Louvain-la-Neuve. <https://www.researchgate.net/publication/23732235_Grants_Versus_Tax_Sharing_the_Extent_of_Central_Government_Control>.

Ruśkowski,, E., Salachna, J.M. (2007). Finanse lokalne po akcesji. Warszawa.

Sekuła, A. (2007). Zmiany w poziomie dochodów gmin województwa pomorskiego w latach 1999 2004, [w:] D. Strahl (red.), Gospodarka lokalna i regionalna w teorii i praktyce. Prace Naukowe 1161. Akademia Ekonomiczna. Wrocław: 574-585. 
Sekuła, A. (2014). Analiza dochodów z udziału we wpływach z podatku dochodowego od osób fizycznych w gminach województwa pomorskiego, [w:] J. Sokołowski, M. Sosnowski (red.), Finanse publiczne. Prace Naukowe Uniwersytetu Ekonomicznego we Wrocławiu nr 346: $235-245$.

Sochacka-Krysiak, H. (2008). Lokalne daniny publiczne jako źródło dochodów własnych samorządu terytorialnego - doświadczenia i perspektywy, [w:] S. Kańduła (red.), Współczesne problemy finansów i gospodarki jednostek samorządu terytorialnego. Poznań: Wydawnictwo Akademii Ekonomicznej w Poznaniu: 11-24.

Surówka, K. (2004). Kierunki zmian systemu zasilania budżetów jednostek samorządu terytorialnego. Zeszyty Naukowe Wyższej Szkoły Ekonomicznej w Bochni 2: 21-27.

Surówka, K. (2008). Adekwatność dochodów JST w Polsce do zakresu realizowanych zadań bieżących po roku 2003, [w:] S. Kańduła (red.), Współczesne problemy finansów i gospodarki jednostek samorządu terytorialnego. Poznań: Wydawnictwo Akademii Ekonomicznej w Poznaniu: 430-439.

Swianiewicz, P. (2004). Finanse lokalne teoria i praktyka. Municipium. Warszawa.

Wójtowicz, K. (2014). Udział w podatkach państwowych a problem stabilności fiskalnej jednostek samorządu terytorialnego w Polsce. Annales Universitatis Mariae Curie-Skłodowska Lublin - Polonia Sectio H 48(2): 136-143.

Wójtowicz, K. (2013). Udziały samorządów w podatkach państwowych - własne czy obce źródło dochodów JST? Dylematy teorii a praktyka budżetowa wybranych państw. Prace Naukowe Uniwersytetu Ekonomicznego we Wrocławiu 306: 501-512.

Zax, J.S. (1988). The effects of jurisdiction types and numbers on local public finance, [w:] H.S. Rosen (ed.), Fiscal Federalism: Quantitative Studies. Chicago: Chicago University Press: 79-106.

\section{SHARE IN PERSONAL INCOME TAX AS THE REVENUE OF \\ MUNICIPALITIES IN POLAND - CONTROVERSY OVER THE RULES OF DISTRIBUTION. A CASE STUDY OF VOIVODESHIP CITIES}

\section{Sum mary}

In the literature, there has been a discussion for years on the legitimacy of granting shares in central taxes to local government units (LGUs) as a source of revenue, and including them in their own revenue. Despite the fact that local authorities consider of this type of revenue sources as a good one, they see a problem in the principles of their distribution. In the case of the Polish personal income tax (PIT), funds are allocated to units according to the taxpayer's place of residence, which means that many people who use local public goods and services from one unit pay the income tax allocated to another one. This applies especially to large cities. The paper characterizes the share in PIT as a source of revenue for municipalities in Poland and estimates the amount of funds lost by municipalities as a result of pointed problems resulting from the adopted method of this revenue distribution between units. Voivodeship cities were chosen as the subjects of the research, and the time scope covered the years 2016 and 2011. The data used to estimate the amount of potential revenue loss of cities come from the resources of the Central Statistical Office and the Ministry of Finance. The estimates confirm that the loss of potential revenue from the analysed source would have a significant fiscal impact for voivodship cities. They would constitute slightly more than $3 \%$ of their own revenue and nearly $8 \%$ of revenue from participation in PIT.

Keywords: own revenue of municipalities; tax sharing; municipalities revenue from shares in personal income taxes; commuting to work; JEL codes: H7 